Egypt. Acad. J. biolog. Sci., 2 (1): 45- 51 (2010)

Email: egyptianacademic@yahoo.com

Received: 25/4/2010
F. Toxicology \&Pest control

ISSN: 2090 - 0791

www.eajbs.eg.net

\title{
Toxicity and Biological effect of Capparis leaves extracts to the black cutworm, Agrotis ipsilon (Hufn.)
}

\author{
Mahasen M. A. El-Shershaby \\ Plant Protection Research Institute, Agriclture Research Center, \\ Giza, Egypt
}

\begin{abstract}
Three different concentrations (20,10 and 5\%) of ethanol, ethyl acetate, diethyl ether and chloroform extracts of Capparis aegyptia plant leaves were tested against $2^{\text {nd }}$ instar larvae of Agrotis ipsilon to study the toxicity and their effects on some biological parameters under laboratory conditions. Maximum mortality percentage was $40 \%$ at $5 \%$ of ethyl acetate extract, while treatment with ethanol extract recorded the lowest mortality percentages especially at 5\%. Calculated $\mathrm{LC}_{50}$ was ranged between 5.752 and 8.027 at treatments with ethanol extract and chloroform extract, respectively. Low concentrations were almost more toxic than high. Malformation percentages of emerged adults were observed with ethanol and diethyl ether extracts. Fecundity reduction percentages at treatments in comparison with control reached the maximum $(100 \%)$ at treatment with ethyl acetate extract while the minimum was about $50 \%$ at chloroform extract treatment.
\end{abstract}

INTRODUCTION

Several crops naturally infested with many noctuid insect pests in the field resulting unlimited yield loss. The black cutworm, Agrotis ipsilon (Hufn.) is considered the most notorious and destructive phytophagous insect pest in Egypt, not only to cotton but also to many field crops and vegetables (Salama et al., 1970 and Kandil et al., 2003).

The excessive use of insecticides, particularly those with long residual effect, resulted in several harm to the natural balance between pests and their enemies by killing many non-target organisms, long storage and some times very slow degradation of the insecticides and in many cases high toxicity to mammals (Schmidt, 1986). In an endeavour to overcome this defect, entomologists are concerned to use alternative approaches to control insect pests. One of these approaches is the use of natural pesticides. These materials have a relatively low mammalian toxicity as compared to many chemical pesticides (Ahmed et al., 1984)
Plants of the genus Capparis (Family: Capparaceae) have been a subject of interest to some investigators from the phytochemical point of view and in particular its glucosinolate content (Kjaer, 1961 and Brown, 1964). Investigation of the medicinal plant Capparis aegyptia L., revealed the presence of alkaloids, glucosinolates, sterols and flavonoids (Hammouda et al., 1975) as well as cumarins, rutic acid, saponins and pectic acid (Ahmed et al., 1972).

The objective of the present work is to study the efficacy of ethanol, ethyl acetate, diethyl ether and chloroform extracts of Capparis aegyptia plant leaves on its toxicity and some biological parameters of black cutworm, Agrotis ipsilon.

\section{MATERIAL AND METHODS}

1- Rearing of Experimental Insect

Pupae of the black cutworm, A. ipsilon were supplied from a laboratory, Department of Cutworm and Mole Crickets, Plant Protection, Research Institute, Agriculture Research Center. Emerged adults were kept in a glass jar 
at ratio $(1 \quad \hat{O}: 19)$, jars were supplied with onion-skin paper and covered with black gauze for laying eggs. For adults feeding a piece of cotton soaked with $20 \%$ honey solution was used. Hatched larvae were reared in plastic cages $(20 \mathrm{x}$ $30 \times 50 \mathrm{~cm}$ ) supplied with tissue paper for moisture and castor oil leaves for feeding. After the third moulting, larvae reared individually to avoid cannibalistic behaviour (El-Shershaby, 2010).

\section{2- Preparation of Extracts a)- Plant Materials}

Leaves of the wild plant, C. aegyptia (C. spinosa var. aegyptia Boiss.) (Family: Capparaceae), were collected from different areas of South Sinai and left to dry at room temperature.

\section{b) - Extract Preparation}

Crude extract of dry powder of plant leaves was prepared using 4 different solvents, Ethanol, Ethyl acetate, Chloroform and Diethyl ether according to Su and Horvat (1981).

\section{c) -Tested Concentrations}

Three different concentrations (20, 10 and 5\%) of each extract were prepared using distilled water and tween-20 (3-5 drops) as an emulsifier and a magnetic stirrer was used for mixing.

\section{3- Experiments}

Newly moulted $2^{\text {nd }}$ instar larvae of A.ipsilon were collected from the stock culture to use in the experiments. Plastic cups $(5 \mathrm{~cm}$ in diameter and $4 \mathrm{~cm}$ height) were used; each cup contains 5 larvae of $2^{\text {nd }}$ instar, confined with treated piece of castor oil leaf (using dipping technique) for feeding and a tissue paper to reduce the moisture. Cups were covered with gauze material and incubated at controlled constant conditions of $25 \pm 2^{\circ} \mathrm{C}$ and $50-60 \% \mathrm{RH}$ and day light.

Five cups were used as replicates/concentration/extract.

Untreated food was used in check cups.

Two days post treatment; larvae were transferred individually into clean cups, which supplied with untreated food and a small piece of tissue paper until pupation. The whole tests were repeated 5 times.

Percentages of larval, prepupal and pupal mortality, deformed and nondeformed emerged adults in addition to fecundity and fertility of treatments and control were recorded.

To determine the effect of tested extracts on fecundity and fertility of emerged adult females from treated larvae, moths were kept in a glass jar and fed on $20 \%$ honey solution. Black paper sheets were hanged up inside the jars for oviposition. Five jars were used as replicates per concentration and the same number were used as control. Total number of laid eggs per replicate was counted and the percentage of hatchability was calculated for treatments and control.

Insect rearing and all experiments were carried out at controlled conditions of $25 \pm 2{ }^{\circ} \mathrm{C}, 50$ $60 \%$ RH and day light.

\section{Statistical analysis}

Statistical analysis was carried out using Analysis of Variance (one way ANOVA) test through "SPSS-Computer Program". Means were compared using Duncann's Multiple Range test. Percentage of mortality was corrected according to Abbott' s formula (Abbott, 1925), the Probit Analysis was applying for calculating $\mathrm{LC}_{50}$ according to Finney (1952).

\section{RESULTS}

Data in table (1) reflect the different mortality responses of the treated Agrotis ipsilon $2^{\text {nd }}$ larval instar. The highest percent mortality (40\%) was recorded for ethyl acetate extract at $5 \%$ concentration, where the lowest percentage mortality (5\%) was recorded for ethanol extract at the same concentration. The other extracts with the tested concentrations reflects different mortality percentage ranged between 10 and $30 \%$; being statistically different either between extract or between tested concentrations (Table 1). 
Table (1): Percentage of mortality of A. ipsilon larvae treated at $2^{\text {nd }}$ instar with C. aegyptia extracted leaves using different solvents

\begin{tabular}{|c|c|c|c|c|c|c|}
\hline \multirow{2}{*}{$\begin{array}{c}\text { Concentration } \\
(\%)\end{array}$} & \multicolumn{6}{|c|}{ Mortality percentage (\%) of treated larvae } \\
\cline { 2 - 6 } & Ethanol & Ethyl acetate & Chloroform & $\begin{array}{c}\text { Diethyl } \\
\text { ether }\end{array}$ & Control & F1-value \\
\hline 20 & $15.0+1.3^{\mathrm{bB}}$ & $10.0+0.7^{\mathrm{cC}}$ & $10.0+0.9^{\mathrm{cC}}$ & $30.0+1.3^{\mathrm{aA}}$ & $8.0+0.7^{\mathrm{C}}$ & $79.873^{* *}$ \\
\hline 10 & $20.0+0.9^{\mathrm{aB}}$ & $15.0+0.9^{\mathrm{bC}}$ & $30.0+0.6^{\mathrm{aA}}$ & $10.0+0.8^{\mathrm{bD}}$ & $8.0+0.7^{\mathrm{D}}$ & $113.016^{* *}$ \\
\hline 5 & $5.0+0.3^{\mathrm{dD}}$ & $40.2+1^{\mathrm{aA}}$ & $25.0+0.6^{\mathrm{bB}}$ & $10.0+0.7^{\mathrm{bC}}$ & $8.0+0.7^{\mathrm{C}}$ & $424.860^{* *}$ \\
\hline Control & $8.0+0.7^{\mathrm{c}}$ & $8.0+0.7^{\mathrm{c}}$ & $8.0+0.7^{\mathrm{c}}$ & $8.0+0.7^{\mathrm{c}}$ & & \\
\hline F2-value & $57.880^{* *}$ & $292.069^{* *}$ & $247.228^{* *}$ & $125.522^{* *}$ & & \\
\hline
\end{tabular}

**= Highly Significant

- Means in columns followed with the same SMALL letters(s) are not significantly different at $5 \%$ level of probability (F1-value).

- Means in rows followed with the same CAPITAL letters(s) are not significantly different at 5\% level of probability (F2-value).

The corrected percentage mortality for larval and pupal stages and the LC-values reflect the reverse effect of all extracts except of diethyl ether, which induced normal effect shape (Table2). The highest concentration
$(20 \%)$ of ethanol, ethyl acetate and chloroform extracts, recorded the lowest percentage mortality, followed by $10 \%$ concentration then the lowest concentration $(5 \%)$ which recorded the highest percent mortality.

Table (2): Mortality percentage of larval and pupal stages of treated $2^{\text {nd }}$ instar larvae

\begin{tabular}{|c|c|c|c|c|}
\hline \multirow{2}{*}{$\begin{array}{c}\text { Concentration } \\
(\%)\end{array}$} & \multicolumn{4}{|c|}{ Corrected mortality (\%) } \\
\cline { 2 - 5 } & Ethanol & Ethyl acetate & Chloroform & Diethyl ether \\
\hline 20 & 21 & 15 & 3 & 72 \\
\hline 10 & 20 & 23 & 57 & 53 \\
\hline 5 & 61 & 62 & 65 & 45 \\
\hline
\end{tabular}

The vies versa, diethyl ether at the highest concentration induced the highest percent mortality, while the lowest concentration $(5 \%)$ recorded the lowest percentage mortality (Table 2) the same trends were observed in table (3) when the needed concentration for killing $25 \%$ of the pupation represented by the highest value, and the needed concentration for killing $90 \%$ of the population was the lowest in case of ethanol, ethyl acetate and chloroform extract; but in case of diethyl ether, the lowest LC-value $\left(\mathrm{LC}_{25}\right)$ represented the lowest concentration $(1.866 \%)$ and the highest $\left(\mathrm{LC}_{90}\right)$ represented the highest concentration $(88.890 \%)$. The survived larvae of A.ipsilon $2^{\text {nd }}$ instar, post treatment, pupate normally as illustrated in figures $(1,2 \& 3)$. It was observed that the latent effects of different extracts could be arranged according to its strength as follows: chloroform $>$ ethanol $>$ ethyl acetate $>$ diethyl ether (at 20\% concentration); being significantly different either among each other or when compared with the check group.

Table (3): Calculated lethal concentrations of extracted C. aegyptia leaves using different solvents

\begin{tabular}{|c|c|c|c|c|}
\hline \multirow{2}{*}{$\begin{array}{c}\text { Calculated } \\
\text { LC }\end{array}$} & \multicolumn{4}{|c|}{ Concentrations at different solvents (\%) } \\
\cline { 2 - 5 } & Ethanol & Ethyl acetate & Chloroform & Diethyl ether \\
\hline $\mathrm{LC}_{25}$ & 13.112 & 11.912 & 13.216 & 1.866 \\
\hline $\mathrm{LC}_{50}$ & 5.752 & 6.098 & 8.027 & 7.073 \\
\hline $\mathrm{LC}_{90}$ & 1.201 & 1.708 & 3.113 & 88.890 \\
\hline Slope & -1.8848 & -2.3195 & -3.1153 & 1.1659 \\
\hline
\end{tabular}




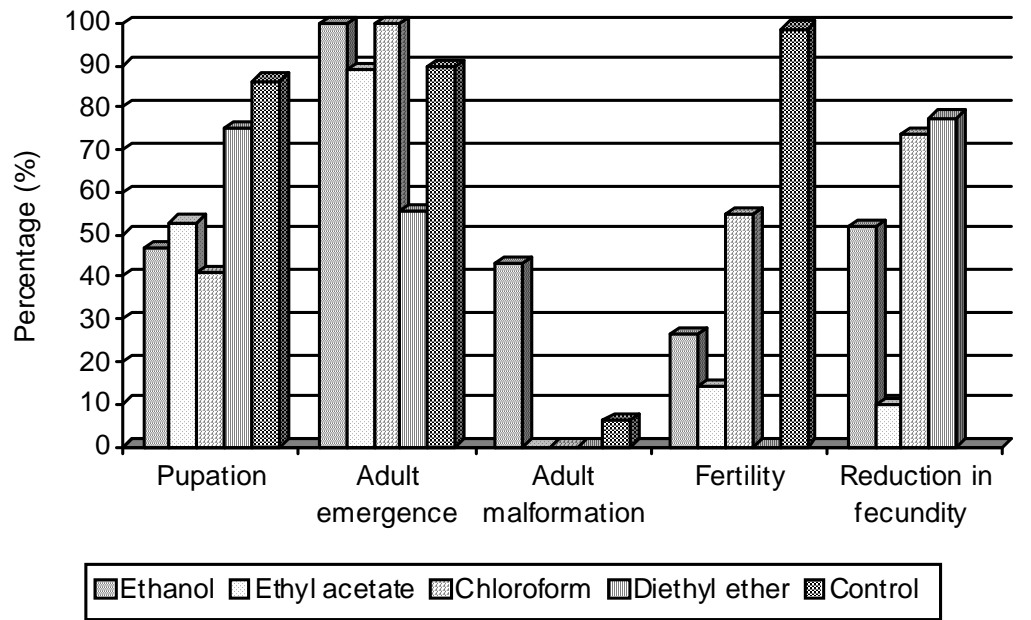

Fig.1: Latent effects of the treatment of the newly moulted $2^{\text {nd }}$ instar larvae with $20 \%$ concentration of different Capparis extracts.

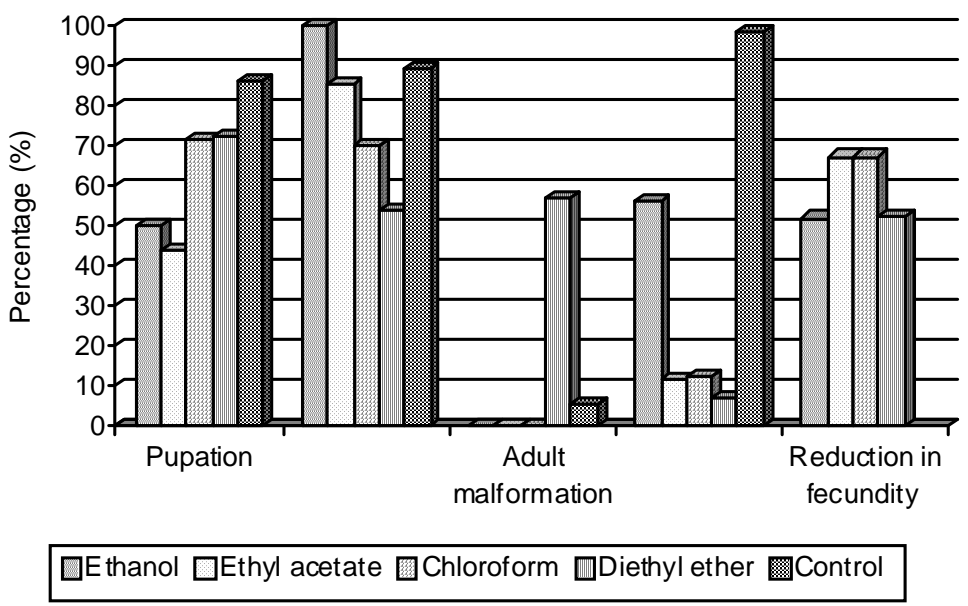

Fig. 2: Latent effects of the treatment of the newly moulted $2^{\text {nd }}$ instar larvae with $10 \%$ concentration of different Capparis extracts.

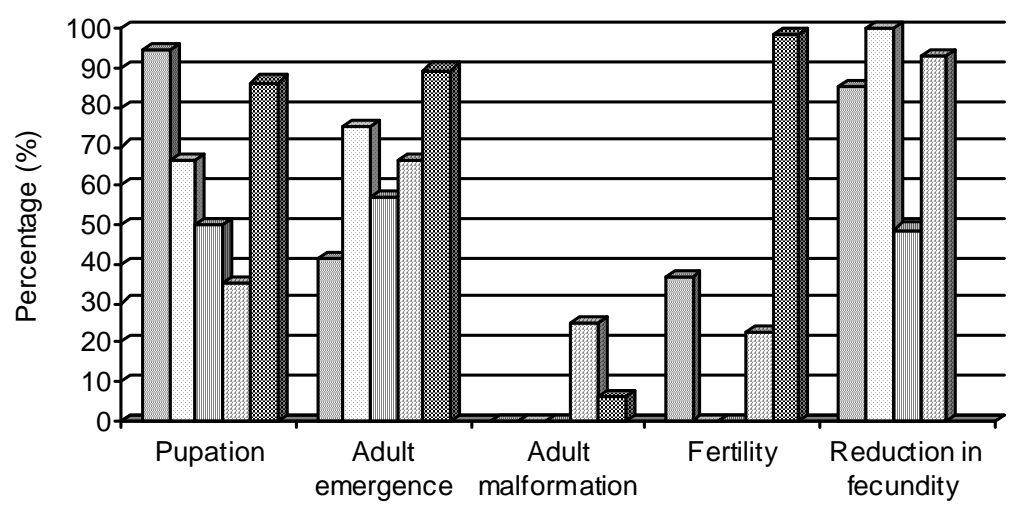

$\square$ Ethanol $\square$ Ethyl acetate $\square$ Chloroform $\square$ Diethyl ether $\square$ Control

Fig. 3: Latent effects of the treatment of the newly moulted $2^{\text {nd }}$ instar larvae with $5 \%$ concentration of different Capparis extracts. 
With going on, the ethanol and chloroform treatment did not affect the adult emergence, where both diethyl ether and ethyl acetate reduced the adult emergence to reach 55.6 and $88.89 \%$, respectively. The fertility of the emerged normal females was affected by the larval treatments, where the fertility reached $0 \%$ in case of diethyl ether, followed by ethyl acetate (14.1\%), ethanol $(26.3 \%)$ then ethanol $(54.6 \%)$. The reduction in fecundity when compared to the check group are 77.6, $73.5,52.0$ and $9.8 \%$ for diethyl ether, chloroform, ethanol then ethyl acetate, respectively, being significantly different between each other (Table 4).

Table (4): Effect of different concentrations of C. aegyptia leaves extracts on the mortality and some biological parameters of $A$. ipsilon

\begin{tabular}{|c|c|c|c|c|c|c|}
\hline \multirow[t]{2}{*}{ Tested item } & \multicolumn{6}{|c|}{$20 \%$ Concentration } \\
\hline & Ethanol & Ethyl acetate & Chloroform & Diethyl ether & Control & F-value \\
\hline Larval mortality (\%) & $15.0+1.3 \mathrm{~b}$ & $10.0+0.7 \mathrm{c}$ & $10.0+0.9 \mathrm{c}$ & $30.0+1.3 \mathrm{a}$ & $8.0+0.7 \mathrm{c}$ & $79.873 * *$ \\
\hline Prepupal mortality (\%) & $11.8+0.4 \mathrm{a}$ & $0 \mathrm{c}$ & $0 \mathrm{c}$ & $0 \mathrm{c}$ & $4.4+0.3 b$ & $498.647 * *$ \\
\hline Pupal mortality (\%) & $0 \mathrm{c}$ & $11.1+0.6 b$ & $0 \mathrm{c}$ & $44.4+1.2 \mathrm{a}$ & $10.5+1.0 \mathrm{~b}$ & $611.528 * *$ \\
\hline Pupation (\%) & $46.7+0.7 \mathrm{~d}$ & $52.9+0.5 \mathrm{c}$ & $41.2+0.7 \mathrm{e}$ & $75.0+1.4 \mathrm{~b}$ & $86.4+0.7 \mathrm{a}$ & $504.750 * *$ \\
\hline Adult emergence (\%) & $100.0+0.0 \mathrm{a}$ & $88.8+0.7 b$ & $100.0+0.0 \mathrm{a}$ & $55.6+1.25 \mathrm{c}$ & $89.5+0.4 b$ & $752.375 * *$ \\
\hline Adult malformation (\%) & $42.9+0.9 \mathrm{a}$ & $0 \mathrm{c}$ & $0 \mathrm{c}$ & $0 \mathrm{c}$ & $5.9+0.1 \mathrm{~b}$ & $204.283 * *$ \\
\hline Fertility $(\%)$ & $26.3+0.5 \mathrm{c}$ & $14.1+0.6 \mathrm{~d}$ & $54.6+0.7 b$ & $0 \mathrm{e}$ & $98.8+0.4 \mathrm{a}$ & $681.368 * *$ \\
\hline Fecundity $(\mathrm{n} . /$ / $)$ & $207.3+6.2 \mathrm{~d}$ & $474.5+3.1 \mathrm{~b}$ & $114.5+2.4 \mathrm{e}$ & $767.0+0.7 \mathrm{a}$ & $431.8+2.6 \mathrm{c}$ & $536.057 * *$ \\
\hline Reduction in fecundity (\%) & $52.0+0.7 \mathrm{c}$ & $9.8+0.3 \mathrm{~d}$ & $73.5+0.8 \mathrm{~b}$ & $77.6+0.5 \mathrm{a}$ & --- & $263.765 * *$ \\
\hline \multicolumn{7}{|c|}{$10 \%$ Concentration } \\
\hline & Ethanol & Ethyl acetate & Chloroform & Diethyl ether & Control & F-value \\
\hline Larval mortality (\%) & $20.0+0.9 \mathrm{~b}$ & $15.0+0.9 \mathrm{c}$ & $30.0+0.6 \mathrm{a}$ & $10.0+0.8 \mathrm{~d}$ & $8.0+0.7 \mathrm{~d}$ & $113.016^{* *}$ \\
\hline Prepupal mortality (\%) & $6.3+0.3 a$ & $0 \mathrm{c}$ & $0 \mathrm{c}$ & $0 \mathrm{c}$ & $4.4+0.3 b$ & $227.085^{* *}$ \\
\hline Pupal mortality (\%) & $0 \mathrm{e}$ & $14.3+0.4 \mathrm{c}$ & $30.0+1.1 \mathrm{~b}$ & $46.2+1.0 \mathrm{a}$ & $10.5+1.0 \mathrm{~d}$ & $478.848 * *$ \\
\hline Pupation (\%) & $50.0+0.6 \mathrm{c}$ & $43.8+0.9 \mathrm{~d}$ & $71.4+0.4 b$ & $72.2+0.5 b$ & $86.4+0.7 \mathrm{a}$ & $689.392 * *$ \\
\hline Adult emergence (\%) & $100.0+0.0 \mathrm{a}$ & $85.3+0.9 \mathrm{c}$ & $70.0+1.2 \mathrm{~d}$ & $53.9+0.9 \mathrm{e}$ & $89.5+0.4 b$ & $495.580 * *$ \\
\hline Adult malformation (\%) & $0 \mathrm{c}$ & $0 \mathrm{c}$ & $0 \mathrm{c}$ & $57.1+0.8 \mathrm{a}$ & $5.9+0.1 \mathrm{~b}$ & $517.678 * *$ \\
\hline Fertility $(\%)$ & $56.1+0.2 b$ & $11.8+0.2 \mathrm{~d}$ & $12.8+0.2 \mathrm{c}$ & $6.8+0.4 \mathrm{e}$ & $98.8+0.4 \mathrm{a}$ & $190.714 * *$ \\
\hline Fecundity (n./P) & $206.7+6.0 \mathrm{c}$ & $723.0+2.9 \mathrm{a}$ & $140.8+1.7 \mathrm{~d}$ & $206.2+1.1 \mathrm{c}$ & $431.8+2.6 \mathrm{~b}$ & $514.249 * *$ \\
\hline Reduction in fecundity (\%) & $52.1+0.3 b$ & $67.4+2.3 \mathrm{a}$ & $67.4+1.8 \mathrm{a}$ & $52.3+1.9 \mathrm{~b}$ & --- & $25.556 * *$ \\
\hline \multicolumn{7}{|c|}{$5 \%$ Concentration } \\
\hline & Ethanol & Ethyl acetate & Chloroform & Diethyl ether & Control & F-value \\
\hline Larval mortality (\%) & $5.0+0.3 \mathrm{~d}$ & $40.2+1.1 \mathrm{a}$ & $25.0+0.6 \mathrm{~b}$ & $10.0+0.7 \mathrm{c}$ & $8.0+0.7 \mathrm{c}$ & $424.860 * *$ \\
\hline Prepupal mortality (\%) & $0 \mathrm{c}$ & $0 \mathrm{c}$ & $0 \mathrm{c}$ & $5.6+0.5 \mathrm{a}$ & $4.4+0.3 b$ & $117.791 * *$ \\
\hline Pupal mortality (\%) & $58.8+0.3 \mathrm{a}$ & $25.0+0.8 \mathrm{~d}$ & $42.9+0.6 \mathrm{~b}$ & $33.3+1.1 \mathrm{c}$ & $10.5+1.0 \mathrm{e}$ & $410.466 * *$ \\
\hline Pupation $(\%)$ & $94.4+1.0 \mathrm{a}$ & $66.7+0.6 \mathrm{c}$ & $50.0+0.9 \mathrm{~d}$ & $35.3+0.7 \mathrm{e}$ & $86.4+0.7 \mathrm{~b}$ & $911.469 * *$ \\
\hline Adult emergence $(\%)$ & $41.2+0.9 \mathrm{e}$ & $75.0+0.8 b$ & $57.1+0.7 \mathrm{~d}$ & $66.7+0.5 \mathrm{c}$ & $89.5+0.4 a$ & $717.650^{* *}$ \\
\hline Adult malformation (\%) & $0 \mathrm{c}$ & $0 \mathrm{c}$ & $0 \mathrm{c}$ & $25.0+0.3 \mathrm{a}$ & $5.9+0.1 \mathrm{~b}$ & $514.088 * *$ \\
\hline Fertility $(\%)$ & $36.7+1.1 \mathrm{~b}$ & $0 \mathrm{~d}$ & $0 \mathrm{~d}$ & $22.5+0.7 \mathrm{c}$ & $98.8+0.4 \mathrm{a}$ & $497.728 * *$ \\
\hline Fecundity $(\mathrm{n} . /+$ ) & $63.7+1.7 \mathrm{c}$ & $0 \mathrm{e}$ & $221.0+1.2 \mathrm{~b}$ & $29.7+0.7 d$ & $431.8+2.6 \mathrm{a}$ & $137.905^{* *}$ \\
\hline Reduction in fecundity (\%) & $85.2+2.2 \mathrm{c}$ & $100.0+0.0 \mathrm{a}$ & $48.8+2.2 \mathrm{~d}$ & $93.1+1.9 b$ & --- & $154.110 * *$ \\
\hline
\end{tabular}

The corresponding figures for 10 and $5 \%$ concentrations of the extracts were more or less gave the same trends (Figs. $2 \& 3)$.

It was clear that the $5 \%$ concentration of extracts was more drastically affected all given parameters when compared with 10 or $20 \%$ of extracts concentration (Table 4 ).

\section{DISCUSSION}

The black cutworm Agrotis ipsilon (Hufn.) is a major pest attack seedlings of many economic plants. It's actually one of the most important insect pests of vegetables and several field crops in Egypt (Salem et al., 1982). The wide range of natural host of the target insect could be increase the resistance to the natural and /or alternative toxic chemicals.

It's interesting that on strictly biochemical criteria polyphagy may enhance the potential of a species to develop resistance, Krieger et al. (1971). Slight toxicity of tested Capparis extracts that obtained in our results may be due to developed resistance of target insect.

Significant reduction in the total number of eggs laid by Tetranychus urticae 
Koch. was recorded during 15 days period for all C. aegptia extracts tested by Hussein et al. (2006). This finding accordance with our results in the reduction percentage of adult female fecundity emerged from treated larvae, which recorded almost more than $50 \%$ reduction in comparison with control.

Our results in toxicity of Capparis extracts and the effect on oviposition of emerged adult from treated larvae of $A$. ipsilon are matched with that found by Upadhyay et al. (2006) they concluded that, extracts of Capparis deidua stems and flowrs showed insecticidal and oviposition inhibitory activities against Bruchus chinensis.

Presence of alkaloid, polyphenols and flavonoids chemical groups in Capparis extracts as stated by Rodrigo et al (1992) and sharaf et al (2000) shed some light on the antifeeding effect of these extracts according that obtained in several studies using such compounds extracted from natural sources and examined against some insect pests (Reyes-Chilpa et al., 1995; Musayimana et al., 2001 and Simmonds, 2001).

Effect of low concentration was more observed than that obtained at higher as shown in our results; this observation may be due to the little amount of food consumption that correlated with very limited active or effective chemical groups at high concentration as a result to the antifeeding effect in contrast that found at low concentration.

\section{REFERENCES}

Ahmed, S.; Grainges, M.; Hylin, J.W.; Mitchel, W.C. and Lit-Singer, S. (1984). Some promising plant species for use as pest control agents under traditional farming systems. Proc. $2^{\text {nd }}$ Int. Neem Conf., Rausisch-holzhausen, 1983. pp. 565-580.

Ahmed, Z.F., Rizk, A.M., Hammouda, F.M. and Seif El-Nasr, M.M. (1972). Phytochemical study of Lantana camara. Terpenes and lactones II. Planta Med. 22, 34-37.

Abbott, W.S. (1925): A method of computing the effectiveness of an insecticide. J. Econ. Entomol., 18: 265-267.
Brown, D.H. (1964). Ph.D Thesis, London University.

El-Shershaby, M.M.A. (2010). Toxicity of heavy metals to Agrotis ipsilon (Hufn) and the entomopathogenic Nematode, Steinernema carpocapsae. Agricultural Research Journal; Suez Canal University. 10(1):101-106.

Finney, D.J. (1952): Probit analysis, $2^{\text {nd }} E d$. Cambridge University Press, London, 318 pp.

Hammouda, F.M.; Seif-El-Nasr, M.M. and Rizk, A.M. (1975). Consittuents of Egyption Capparis species. Pharmazie 29: 747-748.

Hussein, H.; Abou-Elella, M.; Amer, S.A.A. and Momen, F.M. (2006). Repellency and Toxicity of Extracts from Capparis aegyptia $\mathrm{L}$. to Tetranychus urticae Koch. (Acari: Tetranychidae). Acta Phytopathologica et Entomologica Hungarica 41(3-4): 331-340.

Kandil, M.A.; Abdel- Aziz N.F. and Sammour, E.A. (2003). Comparstive toxicity of chlorfluazuron and leufenuron against cotton leaf worm Spodoptera littoralis (Boisd.). Egypt J. Agric. Res., 2: 645-661.

Kjaer, A. (1961). Organic Sulphur Compounds. Pergamon Press, Oxford, NewYork.

Krieger, R.I.; Feeny, P.P. and Wilkinson, C.F. (1971). Detoxication enzymes in the guts of caterpillars: An evolutionary answer to plant defenses? Science 172:579-581.

Musayimana, T., Saxena, R. C., Kairu, E. W., Ogol, C. P. K. O., and Khan, Z. R. (2001). Effects of neem seed derivatives on behavioral and physiological responses of the Cosmopolites sordidus (Coleoptera: Curculionidae). J. Econ. Entomol. 94:449-454.

Reyes-Chilpa, R., Viveros-Rodriguez, N., Gomez-Garibay, F., and AlavezSolano, D. (1995). Antitermitic activity of Lonchocarpus castilloi flavonoids and heartwood extracts. J. Chem. Ecol. 21:455-463.

Rodrigo, M.; Lazaro, M.J.; Alvarruiz, A. and Giner, V. (1992). Composition 
of capers (Capparis spinosa): influence of cultivar, size and harvest date. Journal of Food Science. 57: 1152-1154.

Salama, H.S.; Dimetry, N.Z. and Salem, S.A. (1970). On the host preference and biology of the cotton leaf worm Spodoptera littoralis. Z. ang. Entomol., 67: 261-266.

Salem,Y.S.; El-Kady, E.A. and Abdel Salam, N.M. (1982) Effect of larval host plants on certain biological aspects of Agrotis ipsilon (Hufn). Research Bulletin, Fac. Agric. Ainshams Univ., Egypt. No. 2086.

Schmidt, G.H. (1986). Pestizide und umweltschutz. Vieweg \& Sohu, Braunschweig, 466 pp.

Sharaf, M.; El-Ansari, M.A. and Saleh, N.A.M. (2000). Quercetin triglycoside from Capparis spinosa. Fitoterapia 71: 46-49.

Simmonds, M. S. J. (2001). Importance of flavonoids in insect-plant interactions: Feeding and oviposition. Phytochemistry 56:245-252.

Su, H. and Horvat, R. (1981). Isolation, identification and insecticidal properties of Pipper nigrum amides. J. Agric. Food Chem. 29: 115-118.

Upadhyay, R.K.; Rohatgi, L.; Chaubey, M.K. and Jain, S.C. (2006). Ovipositional responses of the pulse beetle, Bruchus chinensis (Coleoptera: Bruchidae) to extracts and compounds of Capparis decidua. J. Agric.Food Chem. 54: 9747-9751.

\section{ARABIC SUMMARY}

$$
\text { سمية مستخلصات أوراق الكبار المصري وتأثير ها البيولوجي علي يرقات الاودة القارضة السوداء }
$$

\section{Agrotis ipsilon}

$$
\text { معهد بحوث وقاية النباتات محمد أحمد الشرى البحوبي الزراعية }
$$

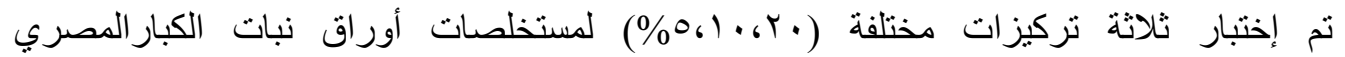

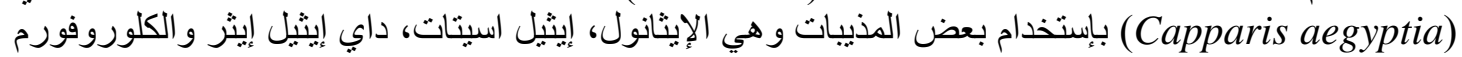

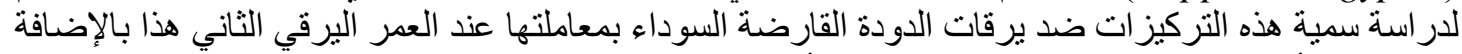

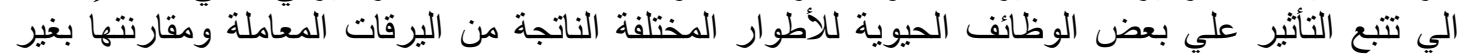

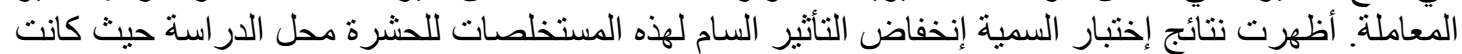

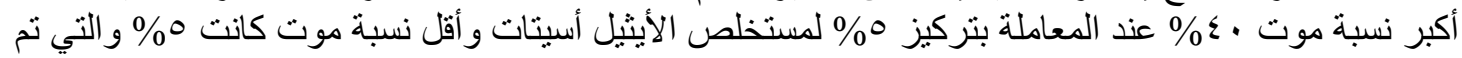

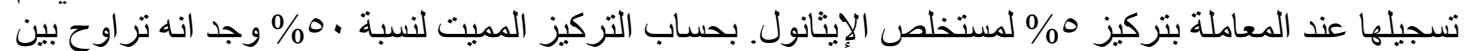

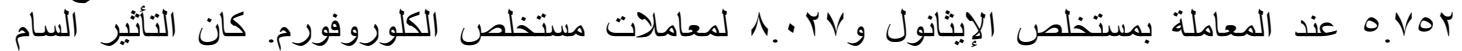

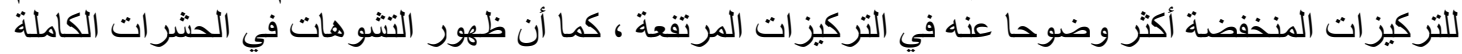

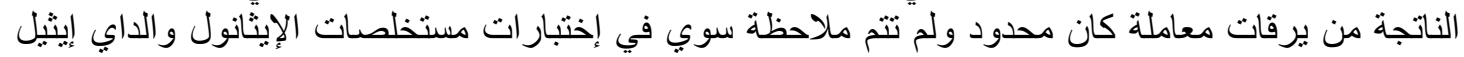

من النتائج أيضا تبين أن نسبة الإنخفاض في خصوبة الإناث الناتجة من يرقات إن معاملة الي غير المعاملة إيثر.

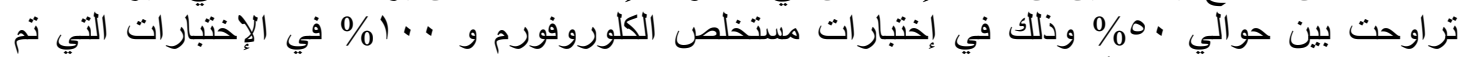
إجر ائها بمستخلص الإيثيل أسيتات. بـن 